\title{
Hypoglycemic Effect Study of a Combination of Some Stipulated Spices in Alloxan Induced Diabetic Wistar Albino Rats along with Nutritional Value Evaluation
}

\author{
Dipa Islam1*, Afsana Akter², Amdadul Huque1, Samina Akhter1, Dipankar Chandra Roy1, \\ Chadni Lyzu', Mahmuda Hakim¹, Liton Chandra Mohanta', Evena Parvin Lipy, \\ Md. Abubakkar Siddique ${ }^{3}$, Khan Md. Murtaja Reza Linkon², Md. Nazibur Rahman4
}

\begin{abstract}
${ }^{1}$ Biomedical and Toxicological Research Institute (BTRI), Institute of Food Science and Technology, Bangladesh Council of Scientific and Industrial Research (BCSIR), Dhaka, Bangladesh

${ }^{2}$ Department of Food Technology and Nutritional Science, Mawlana Bhashani Science and Technology University, Tangail, Bangladesh

${ }^{3}$ WAFFEN Research Laboratory, Dhaka, Bangladesh

${ }^{4}$ Department of Biochemistry and Molecular Biology, Jahangirnagar University, Savar, Bangladesh

Email: ^btr15071@gmail.com
\end{abstract}

How to cite this paper: Islam, D., Akter, A., Huque, A., Akhter, S., Roy, D.C., Lyzu, C., Hakim, M., Mohanta, L.C., Lipy, E.P., Siddique, Md.A., Linkon, K.Md.M.R. and Rahman, Md.N. (2018) Hypoglycemic Effect Study of a Combination of Some Stipulated Spices in Alloxan Induced Diabetic Wistar Albino Rats along with $\mathrm{Nu}-$ tritional Value Evaluation. Journal of Diabetes Mellitus, 8, 43-53.

https://doi.org/10.4236/jdm.2018.82005

Received: April 18, 2018

Accepted: May 18, 2018

Published: May 21, 2018

Copyright (c) 2018 by authors and Scientific Research Publishing Inc. This work is licensed under the Creative Commons Attribution International License (CC BY 4.0).

http://creativecommons.org/licenses/by/4.0/

\begin{abstract}
The main purpose of the study was to reveal the hypoglycemic effect of a combination of some selected spices along with the evaluation of nutritional values. A sum of fourteen different types of spices at different percentages were taken into consideration to propel the research activities forward, viz; ginger, garlic, onion, red chili, turmeric, cumin, cinnamon, clove, coriander, fenugreek, black pepper, nigella, carom seed and cardamom. The healthy experimental wistar albino rats were made diabetic by injecting alloxan monohydrate intraperitoneally a dose of $150 \mathrm{mg} / \mathrm{kg}$ body weight. The rats of Group-D and Group-E were treated with the sample, mixed spices at a dose of $100 \mathrm{mg} / \mathrm{kg}$ and $200 \mathrm{mg} / \mathrm{kg}$ body weight respectively with the lab diet while in case of Group-C, glibenclamide at a dose of $0.5 \mathrm{mg} / \mathrm{kg}$ body weight was introduced with the lab diet for a total period of 21 days where as for the same days span, Group-A and Group-B were continued feeding with only lab diet. Data suggest that the mixed spices of both doses applied in Group-D and Group-E had exerted effects significantly $(p<0.05)$ in lowering the blood glucose level. On $22^{\text {nd }}$ day, in Group-D and Group-E, the FBG level was found to be reduced by around $40.66 \%$ and $41.18 \%$ respectively compared to their respective initial days where in Group-C, the reduction was around $51.90 \%$ in comparison to its initial day. Again, in case of $2 \mathrm{hPG}$ level measurement, on
\end{abstract}


$22^{\text {nd }}$ day, both the groups, Group-D and Group-E were found with the decreased level of around $19.38 \%$ and $39.11 \%$ respectively compared to their respective initial days while the Group-C was shown with the reduced of $44.26 \%$ in comparison adopting same manner. Furthermore, various analyses confirm the presence of several micro and macro nutrients and high amount of dietary fiber in the spices mix. Thus the result affirms that this combined spice possesses strong hypoglycemic properties.

\section{Keywords}

Diabetics, Hypoglycemia, Alloxan Monohydrate, Blood Glucose Level, Nutrients

\section{Introduction}

Diabetes mellitus, usually known as diabetes, is a dysfunction of the endocrine system which causes defects in insulin secretion, and impairs glucose, lipid and protein metabolism [1]. Impairment of insulin secretion and defects in insulin action frequently coexist in the same patient but often remain inexplicit that of which abnormality is the primary cause of hyperglycemia. Loss of weight, polyuria, polydipsia, sometimes with polyphagia, and blurred vision are some of the well-known symptoms of hyperglycemia [2]. If left untreated, it may cause serious complications such as affect to eyes, kidneys, nerves, and blood vessels [3] and is considered to be as one of the leading causes of death in the world. Many appreciable progresses have been made in the management of diabetes using conventional drugs and management strategies, but its complications continue to be a major medical problem. Most of the synthetic oral hypoglycemic drugs available for the treatment of diabetes have serious side-effects and/or cannot be used during pregnancy, and are also costly [4].

Nowadays, compared to drug therapy, a resurgence of interest in using diet to manage and treat diabetes mellitus has emerged in recent years. People are now seeking for natural and herbal sources for the management of the disease. Spices are natural herbs and possess hypoglycemic, hypolipidemic, antioxidant and other useful effects on human health. Spices have minimal or no side-effects rather give synergistic actions [5].

In this study, fourteen different types of spices were used in a combination, to evaluate their effect in lowering blood glucose level. Many of the spices have anti-diabetic effect individually, but when they are used in a mix, their effect is expected to be increased [6]. Allium sativum (garlic) contains bioactive component allicin, which gives antioxidant properties as well as hypoglycemic and anticancer effect [7]. Quercetin is another bioactive component found in Allium cepa $L$. (onion) that has hypoglycemic effect [8]. Allium cepa also facilitates bowel movements and erections, and relieve headaches, coughs, snakebite, and hair loss. Zingiber officinale (Ginger) shows anti-diabetic effect due to the presence 
of bioactive component B-type procyanidin as well as possess anti-cancer, anti-inflammatory, anti-Alzheimer and antioxidant effect [9]. Curcuma longa (turmeric) has another bioactive component curcumin which also shows anti diabetic effect [10]. Cuminum cyminum (cumin) contains bioactive compounds like cuminaldehyde, cuminol which have insulinotropic effect [11]. Cinnamomum potentiates insulin action by the bioactive components, Cinnamaldehyde and A-type procyanidin that are responsible for its hypoglycemic, hypolipidemic and antioxidant effect [12]. Elettaria cardamomum (cardamom), Syzygium aromaticum (clove), Coriandrum sativum (coriander), Trigonella foenum-graecum (fenugreek) exhibits hypoglycemic and anti-oxidant effect [13] [14] [15] [16]. Black Cumin (Nigella sativa), Black pepper (Piper Nigrum L.) are rich in various phyto-chemicals that exerts antioxidant, antimicrobial, anti-inflammatory, antidiabetic, gastro-protective, and antidepressant properties [17] [18] [19]. Capsicum annuum L. (red chilli) is considered to be a safe and effective topical analgesic agent in the management of arthritis pain, diabetic neuropathy, herpes zoster-related pain, mastectomy pain, and headaches [20]. Spices are also said to improve insulin sensitivity or inhibition of endogenous glucose production [21]. The spices are acclaimed furthermore to modulate different metabolic paths and thus help in lowering the glucose level [22].

\section{Materials and Methods}

\subsection{Spices Collection and Preparation}

Raw spices (ginger, garlic, onion, red chili, turmeric, cumin, cinnamon, clove, coriander, fenugreek, black pepper, nigella, carom seed and cardamom) were collected from the local market followed by thorough washing and air drying sequentially using an air oven (UF 260, Memmert, Germany) at $40^{\circ} \mathrm{C}$ for 24 hours. Then the dried spices were grinded and mixed into fine minuscule homogeneous powders, having size of $<0.5 \mathrm{~mm}$ passing through 35 -mesh sieve which were later on stored in an air tight glass jar at room temperature in dry place. The ratio of spices in the mixture is defined (Table 1 ).

\subsection{Chemicals Used}

Alloxan monohydrate, Glucose estimation kit and different standards for heavy metal evaluations were used.

\subsection{Proximate Analysis of the Spice Mix}

Moisture, ash, protein, fat and total dietary fiber contents were measured by AOAC-934.01, AOAC-942.05, AOAC-988.05, AOAC-2003.06, AOAC-985.25 methods respectively.

\subsection{Atomic Absorption Spectrophotometer (AAS) Analysis}

AAS (AAS-7000, Shimadzu, Japan) was used in this experiment for the identification and quantification of heavy metals and essential minerals. Sample 
Table 1. Ratio of spices in the Mixture.

\begin{tabular}{cc}
\hline Spices Name & Percentage (\%) \\
Onion & 14.5 \\
Garlic & 25 \\
Ginger & 7 \\
Red chilli & 15 \\
Turmeric & 12 \\
Cumin seed & 7 \\
Coriander & 10 \\
Cardamom & 1 \\
Black pepper & 1 \\
Cloves & 1 \\
Fenugreek & 2 \\
Nigella & 2 \\
Cinnamon & 2 \\
Carom seed & 0.5 \\
\hline
\end{tabular}

preparation includes digestion and dilution where around $0.5 \mathrm{~g}$ of water was taken to teflon vessel which was then mixed with $7 \mathrm{ml}$ of $\mathrm{HNO}_{3}$ and $1 \mathrm{ml}$ of $\mathrm{H}_{2} \mathrm{O}_{2}$ and allowed to digestion on microwave digester (Ethos One, Milestone, USA) according to the digestion program (Program: power $1600 \mathrm{w} 100 \%$, Ramp time 15 minutes, Temperature $1400^{\circ} \mathrm{C}$, hold time 15 minutes and cooling time 10 minutes.) [23]. Finally, after competition of the digestion procedure, the digested mixture was diluted based on requirements.

\subsection{Experimental Animals}

Experimentally fit, healthy Wistar Albino male rats, weighing around 210 - 230 gm were considered for the hypoglycemic study. All the experiments conducted in this study were approved by the Animal Care Committee of Bangladesh Council of Scientific and Industrial Research (BCSIR). The optimum environmental conditions for the experimental rats were ensured, kept under continual surveillance for period of one week and maintained at a steady room temperature of $25^{\circ} \mathrm{C} \pm 5^{\circ} \mathrm{C}$ along with the humidity of $40 \%$ to $70 \%$ having natural $12 \mathrm{~h}$ day-night cycle. All the rats were fed with the laboratory diet formulated by Institute of Food Science \& Technology, BCSIR, Bangladesh.

\subsection{Preparation of Diabetic Rats}

The weighed amount of alloxan monohydrate was dissolved in distilled water and injected intraperitoneally into the rats of interested groups at a dose of 150 
$\mathrm{mg} / \mathrm{kg}$ body weight and observed the Fasting Blood Glucose (FBG) level after 72 hours of treatment [24]. All the rats were found with the FBG level of more than $7.0 \mathrm{mmol} / \mathrm{l}$ which was an obvious indication of induction of diabetes inside rats.

\subsection{Experimental Procedure}

Thirty male Wistar albino rats (210 - 230 g) were randomly divided into five groups comprising six rats in each to examine the hypoglycemic effects of the mixed spices. These are as follows:

1) Group-A (Normal Control, rats fed with $100 \%$ Lab Diet);

2) Group-B (Alloxan induced diabetic rats fed with $100 \%$ Lab Diet, Diabetic Control);

3) Group-C (Alloxan induced diabetic rat fed Lab Diet plus Glibenclamide, given at a dose of $5 \mathrm{mg} / 10 \mathrm{ml}(9.9 \mathrm{ml} \mathrm{H} 2 \mathrm{O}+0.1 \mathrm{ml}$ Twin 20)/kg body weight, Drug Control [25].

4) Group-D (Alloxan induced diabetic rats fed with mixed spices at a dose of $100 \mathrm{mg} / \mathrm{kg}$ body weight plus lab diet.

5) Group-E (Alloxan induced diabetic rats fed with mixed spices at a dose of $200 \mathrm{mg} / \mathrm{kg}$ body weight plus lab diet.

It was worth mentioning that acute toxicity tests of the mixed spices of both aforementioned doses were conducted and found no adversities exerted by the given doses of spices.

\subsection{Estimation of Blood Glucose Level}

Fasting blood glucose (FBG) and two hours post prandial glucose (2hPG) levels were estimated by using a glucometer (GlucoLeader ${ }^{\mathrm{TM}}$ Enhance, Hsinchu, Taiwan) at $\mathrm{mmol} / \mathrm{l}$ level. Blood glucose levels of both cases were measured at the initial day, $12^{\text {th }}$ day and the $22^{\text {nd }}$ day of experiment.

\subsection{Statistical Analyses}

Data were represented as mean \pm standard deviation (SD) $(n=6)$ value. All statistical analyses were performed using SPSS student version 20. A one-sample T-Test was used to determine significant differences among treatment means and the level of significance was set at $\mathrm{p}<0.05$.

\section{Results and Discussion}

\subsection{The Effect of Mixed Spices on Fasting Blood Glucose (FBG) Concentration of Alloxan Induced Diabetic Rats}

According to WHO, FBG level between $6.1-6.9 \mathrm{mmol} / \mathrm{l}$ is regarded as prediabetes stage (below $6.1 \mathrm{mmol} / \mathrm{l}$ is considered as normal) while that level at 7.0 $\mathrm{mmol} / \mathrm{l}$ or more indicates the onset of diabetes.

The effects of combined spices on FBG level are depicted in Table 2. Here it is worth mentioning that blood sample of each rat was collected, followed by FBG level measurement at eleven days interval including the initial day. Based on data 
presented, it is quite obvious to narrate that mixed spices imparted significant ( $\mathrm{P}$ $<0.05)$ impacts in lowering the blood glucose level.

Table 2. Chronic effect of Spice mix on fasting blood glucose concentration of alloxan induced type 2 diabetic model rats.

\begin{tabular}{cccc}
\hline Group & $\begin{array}{c}\text { FBG at Initial day } \\
(\mathrm{mmol} / \mathrm{L})\end{array}$ & $\begin{array}{c}\text { FBG at } 12^{\text {th }} \text { day } \\
(\mathrm{mmol} / \mathrm{L})\end{array}$ & $\begin{array}{c}\text { FBG at 22 } \\
(\mathrm{mmol} / \mathrm{L})\end{array}$ \\
\hline A $(\mathrm{n}=6)$ & $4.80 \pm 0.53$ & $5.20 \pm 0.45$ & $5.10 \pm 0.21$ \\
B (n=6) & $13.90 \pm 0.33$ & $12.30 \pm 0.15$ & $13.30 \pm 0.25$ \\
C (n=6) & $13.10 \pm 0.38$ & $8.90 \pm 0.38^{*}$ & $6.30 \pm 0.16^{*}$ \\
D (n=6) & $15.00 \pm 0.47$ & $11.20 \pm 0.89^{*}$ & $8.90 \pm 0.96^{*}$ \\
E (n=6) & $11.90 \pm 0.58$ & $9.80 \pm 0.57^{*}$ & $7.00 \pm 0.33^{*}$ \\
\hline
\end{tabular}

Data are presented as Mean \pm SD and compared to the respective previous interval date's value using one way ANOVA (Bonferroni post hoc test), $\mathrm{n}=$ number of rats. ${ }^{*} \mathrm{P}<0.05$.

Data reveals that the mixed spices of both doses have profound impacts in lowering the blood glucose level. The values of Group-A and Group-B stands for the authentication of the control group and prove that lab diet has no significant role on the blood glucose level. By comparing among the groups it was found that with the increment of time span of treatment with mixed spices, FBG level showed decline tendency. On the $22^{\text {nd }}$ day, in Group-D and Group-E, the FBG level was measured to be lessened by around $40.66 \%$ and $41.18 \%$ respectively compared to their respective initial days where in Group-C in which a known anti-diabetic drug named "glibenclamide" was added, the decrease was almost $51.90 \%$ in comparison to its initial day.

\subsection{The Effect of Mixed Spices on Two Hours Post-Prandial Glucose (2hPG) Concentration of Alloxan Induced Type 2 Diabetic Model Rats}

Blood glucose level measured after two hours of feeding is known as 'two hours post-prandial glucose' (2hPG). In this case, WHO delimits the level between 7.8 to $11.0 \mathrm{mmol} / \mathrm{l}$ as prediabetes (below $7.8 \mathrm{mmol} / \mathrm{l}$ is considered as normal) and value higher than that as diabetes.

The effects of mixed spices on $2 \mathrm{hPG}$ level are delineated in Table 3. Blood samples were collected every eleven days interval after two hours of feeding and found that mixed spices played significant $(\mathrm{P}<0.05)$ role in diminishing the blood glucose level.

The values obtained during measurements of $2 \mathrm{hPG}$ level disclose the capability of mixed spices in reducing the blood glucose level. Calculating the decrease percentage, it is seen that on $22^{\text {nd }}$ day, both the groups, Group-D and Group-E were observed with the decreased level of $2 \mathrm{hPG}$ around $19.38 \%$ and $39.11 \%$ respectively compared to their respective initial days while the Group-C where glibenclamide was introduced was found with the reduced of $44.26 \%$ in comparison adopting same manner. 
Table 3. Chronic effect of spice mix on two hours post-prandial glucose concentration of alloxan induced type 2 diabetic model rats.

\begin{tabular}{|c|c|c|c|}
\hline Group & $\begin{array}{c}2 \mathrm{hPG} \text { at } \\
\text { Initial day }(\mathrm{mmol} / \mathrm{L})\end{array}$ & $\begin{array}{c}2 \mathrm{hPG} \text { at } \\
12^{\text {th }} \text { day }(\mathrm{mmol} / \mathrm{L})\end{array}$ & $\begin{array}{c}2 \mathrm{hPG} \text { at } \\
22^{\text {nd }} \text { day }(\mathrm{mmol} / \mathrm{L})\end{array}$ \\
\hline$A(n=6)$ & $6.20 \pm 0.23$ & $6.70 \pm 0.43$ & $6.90 \pm 0.28$ \\
\hline $\mathrm{B}(\mathrm{n}=6)$ & $18.10 \pm 0.30$ & $23.40 \pm 0.24$ & $27.40 \pm 0.25$ \\
\hline$C(n=6)$ & $18.30 \pm 0.48$ & $12.30 \pm 0.24^{*}$ & $10.20 \pm 0.13^{*}$ \\
\hline $\mathrm{D}(\mathrm{n}=6)$ & $16.00 \pm 0.49$ & $14.20 \pm 0.45^{\star}$ & $12.90 \pm 0.46^{*}$ \\
\hline$E(n=6)$ & $17.90 \pm 0.43$ & $13.30 \pm 0.67^{\star}$ & $10.90 \pm 0.44^{*}$ \\
\hline
\end{tabular}

Data are presented as Mean $\pm \mathrm{SD}$ and compared to the respective previous interval date's value using one way ANOVA (Bonferroni post hoc test), $\mathrm{n}=$ number of rats. ${ }^{*} \mathrm{P}<0.05$.

\subsection{The Effect of Mixed Spices on Body Weight of Alloxan Induced Diabetic Rats}

Table 4. The effect of mixed spices on body weight (BW) of alloxan induced diabetic rats.

\begin{tabular}{cccc}
\hline Group & $\begin{array}{c}\text { BW at } 1^{\text {st }} \\
(\mathrm{gm})\end{array}$ & $\begin{array}{c}\text { BW at } 12^{\text {th }} \\
(\mathrm{gm})\end{array}$ & $\begin{array}{c}\text { BW at } 22^{\text {nd }} \text { day } \\
(\mathrm{gm})\end{array}$ \\
\hline A $(\mathrm{n}=6)$ & $224 \pm 2.06$ & $227 \pm 3.27$ & $229 \pm 3.19$ \\
B $(\mathrm{n}=6)$ & $218 \pm 3.51$ & $222 \pm 2.57$ & $224 \pm 3.25$ \\
C (n=6) & $223 \pm 3.21$ & $223 \pm 2.12$ & $221 \pm 3.00^{*}$ \\
D (n=6) & $220 \pm 3.12$ & $218 \pm 3.21^{*}$ & $218 \pm 2.12$ \\
E (n=6) & $227 \pm 3.01$ & $225 \pm 2.27^{*}$ & $223 \pm 2.11^{*}$ \\
\hline
\end{tabular}

Data are presented as Mean $\pm \mathrm{SD}$ and compared to the respective previous interval date's value using one way ANOVA (Bonferroni post hoc test), $\mathrm{n}=$ number of rats. ${ }^{*} \mathrm{P}<0.05$.

In Table 4, it is found that, body weights of the experimental rats of group-A and group-B increased slightly with the time while among the rats of mixed spices treated groups (group-D and group-E), the body weights showed a constant and to some extend the decreasing tendency. Thus based on the data obtained during experiment, it can be postulated that the mixed spices has own its instinct properties in controlling the weight gain.

\subsection{Proximate Composition of the Mixed Spices}

Table 5. Proximate composition of the mixed spices.

\begin{tabular}{cc}
\hline Nutrient & Amount (\%) \\
\hline Moisture content & $07.27 \pm 0.45$ \\
Fat content & $07.76 \pm 0.89$ \\
Protein content & $17.91 \pm 0.77$ \\
Ash content & $04.6 \pm 0.64$ \\
Dietary Fiber content & $30.51 \pm 0.24$ \\
Crude Fiber & $10.12 \pm 1.00$ \\
Carbohydrate content & $52.34 \pm 1.04$ \\
Total Energy & $350 \mathrm{Kcal} / 100 \mathrm{gm}$ \\
\hline
\end{tabular}

Data are represented as mean \pm SD value $(n=3)$. 
Table 5 represents the proximate composition of the mixed spices. The analyses showed that, macronutrients such as carbohydrate, protein, fat were present in the mixed spices at satisfactory level in all cases. The carbohydrate content of the stipulated mixed spices was $52.34 \%$, which is obviously an adequate amount in terms of spices. Therefore, surely, the sample will meet the daily requirement of carbohydrate. In case of fat content, it was found to have around $7.76 \%$ which is low in amount and good enough in all respects. Again, the dietary fiber content was satisfactorily high $(30.51 \%)$ in the mixed spices which made the recipe unique as many studies showed beneficial effects of dietary fiber in diabetic subjects imparting the blood glucose level lowering capabilities and decreasing the glycemic index of foods [26]. The levels of all other associated nutrients including protein were up to the mark.

Heavy metals are the toxic substances and the absence of any aforementioned heavy metals in the mixed spices authenticates the purity of the recipe from any kind of metallic impurities (Tables 6-7).

Table 6. Essential Mineral contents in the mixed spices.

\begin{tabular}{cc}
\hline Essential minerals & Amount (mg/100gm) \\
\hline Iron & $256 \pm 2.77$ \\
Calcium (Ca) & $267 \pm 4.50$ \\
Magnesium (Mg) & $124 \pm 1.20$ \\
Zinc (Zn) & $17 \pm 0.99$ \\
Potassium (K) & $1348 \pm 1.00$ \\
\hline
\end{tabular}

Data are represented as mean \pm SD value $(n=3)$.

Table 7. Heavy Metal Contents in the mixed spices.

\begin{tabular}{|c|c|c|}
\hline Heavy Metals & Amount (mg/100gm) & Detection limit (ppm) \\
\hline Arsenic (As) & $\mathrm{BDL}$ & 0.10 \\
\hline Lead $(\mathrm{Pb})$ & $\mathrm{BDL}$ & 0.50 \\
\hline Chromium (Cr) & $\mathrm{BDL}$ & 0.05 \\
\hline Copper $(\mathrm{Cu})$ & $\mathrm{BDL}$ & 0.10 \\
\hline Cadmium (Cd) & $\mathrm{BDL}$ & 0.20 \\
\hline
\end{tabular}

${ }^{*} \mathrm{BDL}=$ Below the Detection Limit, $\mathrm{ppm}=$ parts per million

\section{Conclusion}

This is the rudimentary pilot study to evaluate the hypoglycemic activities along with nutritional value evaluation of the selected mixed spices recipe in which fourteen different types of spices are incorporated that they are usually consumed in everyday cooking. It was evident from the experimental data that the mixed spices had lowered the blood glucose level at a very significant level which was full of various essential nutrients. It was also observed that the spices mix- 
ture had natural qualities in preventing weight gain which may be applied in case of high cholesterol related problems. Based on the data obtained from the experiments, it can be asserted that the stipulated mixed spices possess remarkable hypoglycemic properties. Since spices are natural herbs and incur no adverse effects, the stipulated mixed spices recipe may be taken into consideration for the management of diabetes mellitus and obesity.

\section{Acknowledgements}

We are expressing our sincere and outmost gratitude to the Biomedical and Toxicological Research Institute (BTRI), IFST, BCSIR, Dhaka, Bangladesh for both the financial and logistic supports.

\section{References}

[1] Ozougwu, J., Obimba, K., Belonwu, C. and Unakalamba, C. (2013) The Pathogenesis and Pathophysiology of Type 1 and Type 2 Diabetes Mellitus. Journal of Physiology and Pathophysiology, 4, 46-57. https://doi.org/10.5897/JPAP2013.0001

[2] American Diabetes Association AD (2009) Diagnosis and Classification of Diabetes Mellitus. Diabetes Care, 32, S62-67. https://doi.org/10.2337/dc09-S062

[3] Forbes, J.M. and Cooper, M.E. (2013) Mechanisms of Diabetic Complications. Physiological Reviews, 93, 137-188. https://doi.org/10.1152/physrev.00045.2011

[4] Kumari, K.D.K.P., Suresh, T.S., Samarasinghe, K., Handunnetti, S.M. and Samaranayake, T.S.P. (2013) Evaluation of a Traditional Sri Lankan Herbal Beverage (Water Extract of Dried Flowers of Aegle marmelos, Bael Fruit) in Type II Diabetic Patients. Journal of Diabetes \& Metabolism, s4, No. 1.

[5] Panda, A., Jena, S., Sahu, P.K., Nayak, S. and Padhi, P. (2013) Effect of Polyherbal Mixtures on the Treatment of Diabetes. ISRN Endocrinology, 2013, 5.

https://doi.org/10.1155/2013/934797

[6] Otunola, G.A. and Afolayan, A.J. (2015) Antidiabetic Effect of Combined Spices of Allium sativum, Zingiber officinale and Capsicum frutescens in Alloxan-Induced Diabetic Rats. Frontiers in Life Science, 8, 314-323.

https://doi.org/10.1080/21553769.2015.1053628

[7] Thomson, M., Al-Amin, Z.M., Al-Qattan, K.K., Shaban, L.H. and Ali, M. (2007) Anti-Diabetic and Hypolipidaemic Properties of Garlic (Allium sativum) in Streptozotocin-Induced Diabetic Rats. International Journal of Endocrinology and Metabolism, 15, 108-115.

[8] Caridi, D., Trenerry, V.C., Rochfort, S., Duong, S., Laugher, D. and Jones, R. (2007) Food Chemistry Profiling and Quantifying Quercetin Glucosides in Onion (Allium cepa L.) Varieties Using Capillary Zone Electrophoresis and High Performance Liquid Chromatography. Food Chemistry, 105, 691-699.

https://doi.org/10.1016/j.foodchem.2006.12.063

[9] Rahman, H.S., Rasedee, A., Yeap, S.K., Othman, H.H., Chartrand, M.S., Namvar, F., et al. (2014) Biomedical Properties of a Natural Dietary Plant Metabolite, Zerumbone, in Cancer Therapy and Chemoprevention Trials. BioMed Research International, 2014, 20. https://doi.org/10.1155/2014/920742

[10] Zhang, D., Fu, M., Gao, S. and Liu, J. (2013) Curcumin and Diabetes: A Systematic Review. Evidence-Based Complementary and Alternative Medicine, 2013, 16. https://doi.org/10.1155/2013/636053 
[11] Patil, S.B., Takalikar, S.S., Joglekar, M.M., Haldavnekar, V.S. and Arvindekar, A.U. (2013) Insulinotropic and $\beta$-Cell Protective Action of Cuminaldehyde, Cuminol and an Inhibitor Isolated from Cuminum cyminum in Streptozotocin-Induced Diabetic Rats. British Journal of Nutrition, 110, 1434-1443. https://doi.org/10.1017/S0007114513000627

[12] Subash Babu, P., Prabuseenivasan, S. and Ignacimuthu, S. (2007) Cinnamaldehyde-A Potential Antidiabetic Agent. Phytomedicine, 14, 15-22. https://doi.org/10.1016/j.phymed.2006.11.005

[13] Lu, F.-R., Shen, L., Qin, Y., et al. (2008) Clinical Observation on Trigonella Foenum-graecum L. Total Saponins in Combination with Sulfonylureas in the Treatment of Type 2 Diabetes Mellitus. Chinese Journal of Integrative Medicine, 14, 56-60. https://doi.org/10.1007/s11655-007-9005-3

[14] Kuroda, M., Mimaki, Y., Ohtomo, T., Yamada, J., Nishiyama, T., Mae, T., et al. (2012) Hypoglycemic Effects of Clove (Syzygium aromaticum Flower Buds) on Genetically Diabetic KK-A y Mice and Identification of the Active Ingredients. Journal of Natural Medicines, 66, 394-399. https://doi.org/10.1007/s11418-011-0593-Z

[15] Waheed, A., Miana, G.A., Ahmad, S.I. and Khan, M.A. (2006) Clinical Investigation of Hypoglycemic Effect of Coriandrum Sativum in Type-2 (Niddm) Diabetic Patients. Pakistan Journal of Pharmacology, 23, 7-11.

[16] Pasha, H. and Qureshi, H.J. (2017) Pharmacological Effects of Coriander Coriandrum sativum.

[17] Alimohammadi, S., Hobbenaghi, R., Javanbakht, J., Kheradmand, D., Mortezaee, R., Tavakoli, M., et al. (2013) Protective and Antidiabetic Effects of Extract from Nigella Sativa on Blood Glucose Concentrations against Streptozotocin (STZ)-Induced Diabetic in Rats: An Experimental Study with Histopathological Evaluation. Diagnostic Pathology, 8, 137. https://doi.org/10.1186/1746-1596-8-137

[18] Onyesife, C.O., Ogugua, V.N. and Anaduaka, E.G. (2014) Hypoglycemic Potentials of Ethanol Leaves Extract of Black Pepper (Piper Nigrum) on Alloxan-Induced Diabetic Rats. Annals of Biological Research, 5, 26-31.

[19] Nabi, S.A., Kasetti, R.B., Sirasanagandla, S., Tilak, T.K., Kumar, M.V.J. and Rao, C.A. (2013) Antidiabetic and Antihyperlipidemic Activity of Piper longum Root Aqueous Extract in STZ Induced Diabetic Rats. BMC Complementary and Alternative Medicine, 13, 37.

[20] Sandhya, P. and Trupti, N. (2017) Studies on Hypocholesterolemic and Antidiabetic Activity of Capsicum annuum Linn on Diet Induced Obese Rats. Current Traditional Medicine, 9, 921-927.

[21] Ali, L., Azad, K.A.K., Mamun, M.I.R., Mosihuzzaman, M., Nahar, N., Nur, E.A.M. and Rokeya, B. (1993) Studies on Hypoglycemic Effects Fruit Pulp, Seed and Whole Plant of Momordica charantia on Normal and Diabetic Model Rats. Planta Medica, 59, 408-412. https://doi.org/10.1055/s-2006-959720

[22] Petchi, R.R., Vijaya, C. and Parasuraman, S. (2014) Antidiabetic Activity of Polyherbal Formulation in Streptozotocin-Nicotinamide Induced Diabetic Wistar Rats. Journal of Traditional and Complementary Medicine, 4, 108-117. http://www.ncbi.nlm.nih.gov/pubmed/24860734

[23] Milestone Helping Chemists (2015) Application Note. http://www.milestonesrl.com

[24] Akhtar, M.S., Athar, M.A. and Yaqub, M. (1981) Effect of Momordica charantia on Blood Glucose Levels of Normal and Alloxan Diabetic Rabbits. Planta Medica, 42, 205-212. https://doi.org/10.1055/s-2007-971629 
[25] Kuroda, M., Mimaki, Y., Sashida, Y., Mae, T., Kishida, H., Nishiyama, T., et al. (2003) Phenolics with PPAR- $\gamma$ Ligand-Binding Activity Obtained from Licorice (Glycyrrhiza uralensis Roots) and Ameliorative Effects of Glycyrin on Genetically Diabetic KK-Aymice. Bioorganic \& Medicinal Chemistry Letters, 13, 4267-4272. https://doi.org/10.1016/j.bmcl.2003.09.052

[26] Al, P., Jenkins, D.J., Zdravkovic, U., Würsch, P. and Vuksan, V. (2002) Depression of the Glycemic Index by High Levels of Beta-Glucan Fiber in Two Functional Foods Tested in Type 2 Diabetes. European Journal of Clinical Nutrition, 56, 622-628. https://doi.org/10.1038/sj.ejcn.1601367 